\title{
From Agama Hindu Bali to Agama Hindu: Two styles of argumentation ${ }^{1}$
}

\author{
Michel Picard \\ Southeast Asian Center (CASE), \\ National Center for Scientific Research (CNRS), \\ Paris, France \\ Email: mpicard@ehess.fr
}

\begin{abstract}
This paper attempts to compare two different styles of argumentation, composed by Balinese at pivotal turning points of their religious identity. The first one, set in the 1920s, when Balinese intellectuals were starting to assess the foundations of their "Balineseness" (Kebalian), contrasts the argumentation of Bali Adnjana (1924-1930) with that of Surya Kanta (1925-1957), by focusing on the use of dialogue as rhetorical device by Tjakra Tanaja, the editor of Bali Adnjana. The second moment takes place in the 1960s, after the Balinese leaders had succeeded in having their religion officially recognized by the Indonesian Ministry of Religions, under the condition that it would no longer be exclusively theirs. It expounds the Upadeśa Tentang Ajaran-Ajaran Agama Hindu, the Hindu catechism composed by the Parisada Hindu Dharma in 1967, once the dogmatic contents of the Agama Hindu - the Panca Çraddha - had been fully delineated in 1964. While the Upadeśa is also presented in the form of a dialogue between the guru Rși Dharmakīrti and his śisya Sang Suyaśa, its argumentation differs strikingly from the one used in Bali Adnjana.
\end{abstract}

Keywords:Balineseintellectual,balineseness, argumentation, Hindu religion, identity

\begin{abstract}
Abstrak
Tulisan ini mencoba membandingkan dua gaya argumentasi yang berbeda, yang disusun oleh orang Bali saat titik balik penting identitas religius mereka. Yang pertama, yang ditetapkan pada tahun 1920-an, ketika para intelektual Bali mulai menilai dasar "Kebalian" mereka, dengan membandingkan argumentasi Bali Adnjana (1924-1930)
\end{abstract}

1 This paper was presented at the second symposium on "How Indonesians Argue”, organized by Mark Hobart (Deddington, Oxfordshire, 25-26 July 2016). 
dengan Surya Kanta (1925-1957), dengan memusatkan perhatian pada penggunaan dialog sebagai perangkat retoris oleh Tjakra Tanaja, redaktur Bali Adnjana. Yang kedua terjadi pada tahun 1960 -an, setelah para pemimpin Bali berhasil membuat agama mereka diakui secara resmi oleh Kementerian Agama di Indonesia, dengan syarat tidak lagi menjadi milik mereka secara eksklusif. Ini menguraikan Upadeśa Tentang Ajaran-Ajaran Agama Hindu, ajaran Hindu yang disusun oleh Parisada Hindu Dharma pada tahun 1967, yang berisi dogmatik Agama Hindu - Panca Çraddha telah sepenuhnya digambarkan pada tahun 1964 . Sementara Upadeśa juga dipresentasikan dalam bentuk dialog antara guru R̦și Dharmakīrti dan muridnya Sang Suyaśa, argumentasi mereka yang berbeda dengan yang digunakan di Bali Adnjana.

Kata kunci: intelektual Bali, kebalian, argumentasi, agama Hindu, identitas

Tn this paper, I attempt to compare two different styles of Largumentation, composed by Balinese at pivotal turning points of their religious identity: the first one in the 1920s, when Balinese intellectuals were starting to explicitly assess the foundations of their identity; the second in the 1960s, after the Balinese leaders had succeeded in having their religion officially recognized by the Indonesian Ministry of Religions, under the condition that it would no longer be exclusively theirs.

\section{Bali Adnjana (1924-1930) and Surya Kanta (1925-1927)}

The incorporation of Bali into the Dutch East Indies prompted the formation of a Balinese intelligentsia, since the colonial administration needed Dutch-educated natives to mediate between the local population and their foreign masters. The upheaval caused by the colonial occupation of their island compelled these educated Balinese to engage in a process of self-identification.

It wasin the cosmopolitan town ofSingaraja, theadministrative centre of the Residency of Bali and Lombok, that the first generation of Balinese educated in colonial schools (kaum terpelajar) founded Western-style organizations and started publishing periodicals which were innovative in both content and form. Devoted 
chiefly to issues pertaining to socio-religious issues, these publications were written not in Balinese but in Malay, the language of modernity and learning. Thus, the same process which compelled the Balinese to question their identity dispossessed them of their own words, by inducing them to think about themselves in a language that was not their own. Such a linguistic substitution marked a reflexive distancing from the Balinese universe of reference, which was decontextualized, relativized, and homogenized

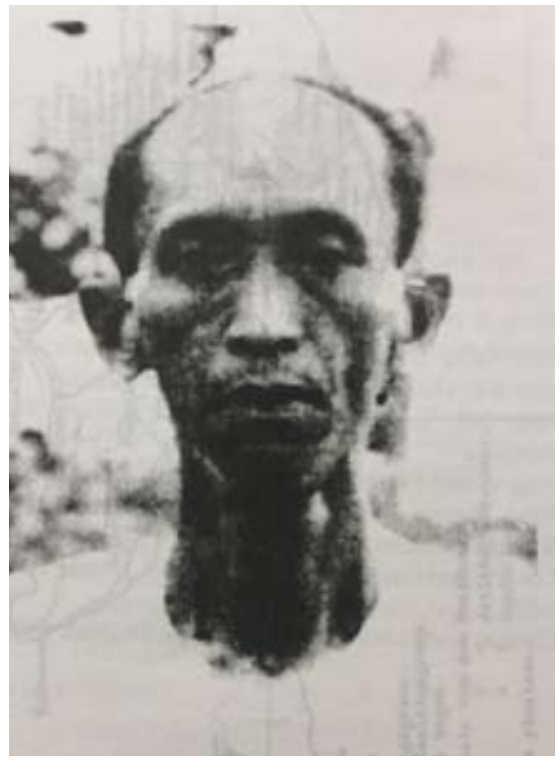

Photo 1. I Goesti Bagoes Tjakra Tanaja (Repro A.A. Putra Agung, 2001) in the process.

The first of these modern organisations, Setiti Bali, was founded in 1917 by I Goesti Bagoes Tjakra Tanaja, the punggawa of Sukasada, to counter the Javanese Islamic association Sarekat Islam, which had recently opened a branch in Singaraja. It lasted until 1920 and was succeeded the following year by a short-lived association called Soeita Gama Tirta, founded by I Ktoet Nasa, the principal of the primary school in Bubunan, and presided by I Goesti Poetoe Djlantik, a descendant of the raja of Buleleng. In 1923, members of a cooperative society founded the Santi association under the leadership of Poetoe Djlantik, Tjakra Tanaja and Ktoet Nasa. In January 1924, they started a publication called Santi Adnjana.

All these organisations had been opened to triwangsa and jaba alike, but tension appears to have been rife between the two groups, the jaba objecting to various privileges claimed by the triwangsa. A conflict soon opposed the leaders of each faction, Tjakra Tanaja and Ktoet Nasa, and sometime in 1924 the publication of Santi Adnjana was taken over by Tjakra Tanaja, who changed its title to Bali Adnjana. The conflict escalated until a split between jaba and triwangsa grew inevitable. This happened through an argument over the Balinese religion during a meeting of the members of Santi 
in May 1925. In October 1925, Ktoet Nasa started publishing his own periodical, Surya Kanta, and the following month he established an eponymous association whose membership was restricted to the jaba. Meanwhile, the membership of Santi was dwindling, as most of the jaba were joining Surya Kanta. In July 1926, Santi held its last meeting and it appeared to cease its activities by the end of the year. The situation became even more confused after May 1926, with the foundation in Klungkung of an organisation named Tjatoer Wangsa Derja

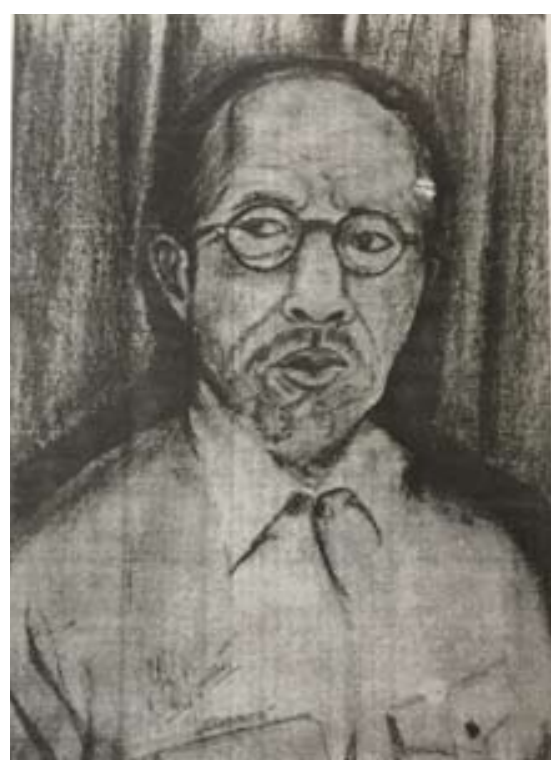

Photo 2. I Ktoet Nasa

(Repro A.A. Putra Agung, 2001)

Gama Hindoe Bali (shortened in

Tjwadega Hindoe Bali). Professing to reconcile the interests of all "four castes" (catur wangsa), this new association was in fact controlled by triwangsa and used Bali Adnjana as its mouthpiece.

In both Bali Adnjana and Surya Kanta, the Balinese authors construed their identity - which they called Kebalian - as being based on agama and on adat (Kebalian kita berdasar agama dan adat) ${ }^{2}$. But whereas the triwangsa were determined to strengthen both tradition and religion, the jaba wanted to reform agama while ridding adat of all the customs they deemed obsolete. In effect, for the former, Balinese religion was based on the customary social order, within which agama was inseparable from adat. Whereas for the latter, religion could and should be dissociated from a traditional order seen not only as unfair but also as an obstacle to progress. Yet, they proved unable to differentiate between that which belongs to agama and that which pertains to adat.

This inability to dissociate agama from adat did not stem solely

2 While these words are usually translated by "religion" and "tradition" nowadays, their genealogy and their appropriation by the Balinese would deserve more space than available in this paper. I have already dealt with these categories in numerous publications. 


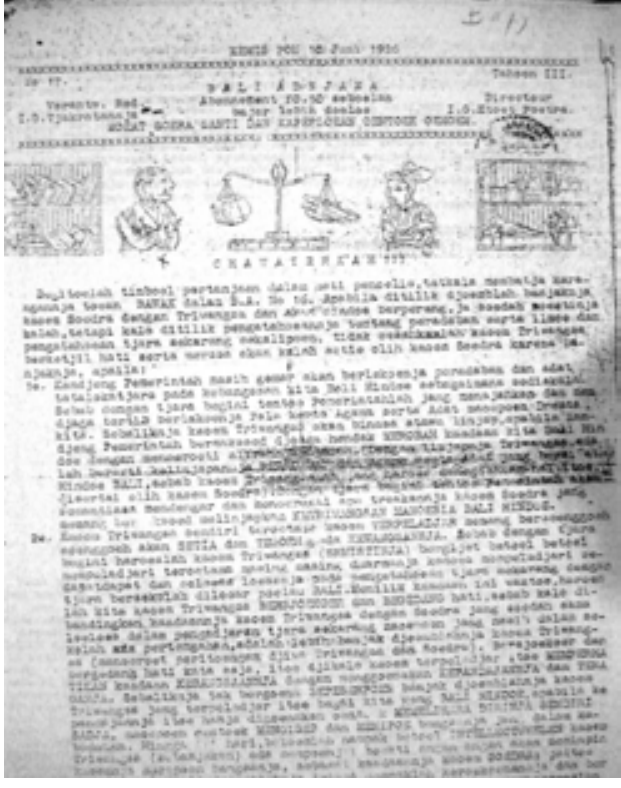

Photo 3. Bali Adnjana

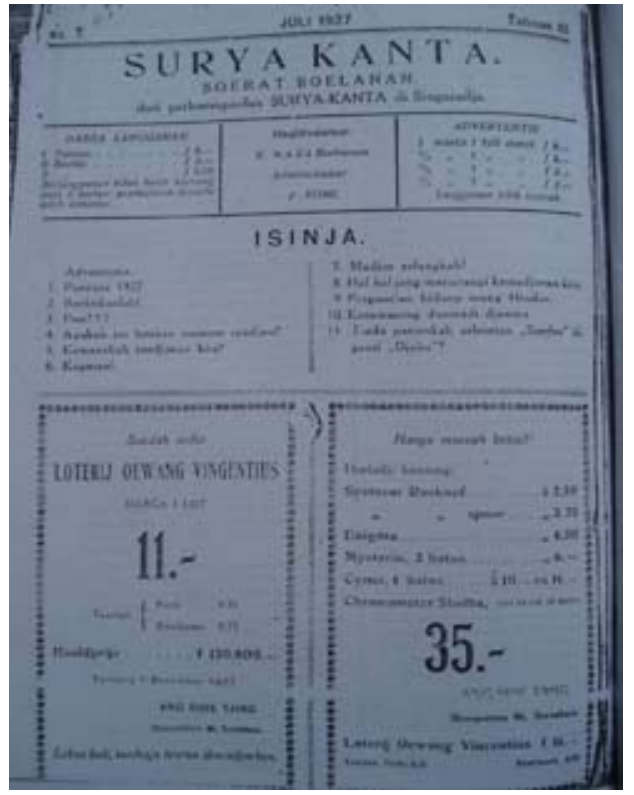

Photo 4. Surya Kanta

from the polysemy of these terms, whose respective semantic fields overlap ${ }^{3}$, but also from the fact that up to that point the Balinese had yet to single out and distinguish a system of beliefs and practices that could be demarcated from other aspects of their life and labelled "religion". Hence the confusion of the Balinese faced with having to name their religion, once they had adopted the word agama for that purpose. At first, it appears that they referred to their religion simply as agama Bali. Afterward, Balinese started using a variety of names for their religion, such as Siwa, Buda, Siwa-Buda, and Tirta.

In May 1925, a dispute erupted between commoners and the nobility over the name of the Balinese religion. The triwangsa proposed to call their religion Agama Hindu Bali, stressing the fact that the Balinese people had appropriated and reinterpreted Agama Hindu $u^{4}$ to such an extent that it had become indigenous to

3 Indeed, in Balinese-Indonesian dictionaries, agama is translated as (1) agama, (2) hukum, and (3) adat-istiadat.

4 Admittedly, we don't know when Balinese actually chose to label their own agama as Hindu. But we do know that long before they began defining themselves as Hindu, the Balinese had already been "Hinduized" by Orientalists, at a time when they had yet to learn the word "Hindu". 
their island. In this way, they were clearly trying to preserve the established socio-religious order, by endorsing the religion actually practised by the Balinese. Whereas in defending the name Agama Bali Hindu, the jaba claimed that the Balinese were truly Hindus, even if their religious practices were corrupt, owing to their ignorance of the true nature of their religion. Consequently, in order to become the true Hindus they were supposed to be, the Balinese should discard all indigenous accretions that contaminated their religious practices. Hence the triwangsa accused the jaba of attempting to promote a form of Hinduism similar to that found in India. This, they claimed, amounted to inventing a new religion, which was alien to the Balinese, because their religion originated not in India but in Majapahit Java.

This issue was to remain pending until Indonesia's independence.

It was not only in their views regarding the Balinese religion that jaba and triwangsa diverged but also in the ways they argue their respective points. Whereas the positions expressed in Surya Kanta are quite straightforward, those in Bali Adnjana tend to be couched in rather allusive and elusive terms. Indeed, the general tenor of each publication is fairly contrasted and the jaba's use of Malay reminds one of the roughness of lower Balinese, while the triwangsa's evokes the literary verbosity of high Balinese. Such a contrast is particularly noticeable in Tjakra Tanaja's use of pseudodialogues as rhetorical devices.

The sentence opening the first issue of Surya Kanta makes clear Ktoet Nasa's purpose:

"Bahwa maksud kami mengeluarkan surat kabar ini, ialah hendak memimpin bangsa Bali yang terbilang 'gelap' budinya dan jauh kebelakang tentang kemajuan hidup didunia ini" (Surya Kanta 1925, n’1: 1).

The Balinese people are still in the dark (kegelapan) and the reforms advocated by Surya Kanta will bring them enlightenment and guide them toward a brighter future, characterized by knowledge (pengetahuan) and progress (kemajuan) - a subliminal message already conveyed by the title of the magazine. The significance of progress for Ktoet Nasa is explained in the article immediately following his statement of intention: 
"Adapun 'Kemajuan' artinya bertambah-tambah sempurna, dan suatu bangsa dikatakan 'berkemajuan', apabila bangsa itu bertambah-tambah sempurna dalam segala sifat kemanusiaan, yaitu segala sifat yang membedakan manusia dari pada hewan" (Surya Kanta 1925, No. 1: 1).

The reforms stipulated in order for the Balinese people to see the light of progress are spelled out in a concise manner in the statutes of that organization, published in the second issue of Surya Kanta: a) to foster reason and character (mengutamakan budi); b) to improve the economy (memperbaiki economie); c) to improve and protect the fate of the commoners (memperbaiki dan melindungi nasib kaum Jaba); d) to change the customs that are contrary to the progress of the times (mengubah adat yang berlawanan dengan kemajuan jaman) (Surya Kanta 1925, No. 2: 16).

The means to these ends is Western-style education (pendidikan cara Barat), which is deemed to be the foundation of progress (pangkal kemajuan). The Balinese are summoned to move forward and advance themselves (memajukan diri), failing which they will be left behind (ketinggalan zaman). Once properly educated, the Balinese will be in a better position to improve their economic situation, which has been deteriorating lately.

Education is expected to enlighten the Balinese people, by supplying them with both "intelligence" (kepandaian) and "reason" (budi). Thanks to these qualities, the Balinese will then know how to discriminate among their customs between those which they should conserve or invigorate and those which they should reform or abandon, in accordance with the "progress of the world" (kemajuan dunia). For whoever keeps defending the customs which are no longer suitable for the present time is guilty of hampering the progress of one's people:

"Barang siapa yang masih membela adat yang tiada dikehendaki lagi oleh zaman, maka orang yang demikian adalah sebagai mengurung jiwa bangsanya didalam peti besi atau menghalangi kemajuan bangsanya" (Surya Kanta 1926, No. 2: 24).

In Bali, the main obstacle to progress is "caste" (kasta) prejudice and the privileges which the triwangsa enjoy in such areas as language, etiquette, marriage, corvee labour, and so on. This is 
no longer acceptable for the jaba, who demand for themselves the same station in life and society as the triwangsa - "solidarity and equality" (sama rata sama rasa) $)^{5}$. In effect, by pursuing education, the jaba will raise their social status and in consequence they will be paid due respect by the triwangsa:

\begin{abstract}
"Haruslah kaum JABA itu BERKEPANDAIAN dan BERBUDHI, sebab [...] kalau ada seorang JABA yang berkepandaian atau berpangkat agak tinggi ia berbudhi serta mengerti pada kemajuan dan tahu 'TATALOKACARA' menurut zaman, maka dapatlah orang JABA berkehormatan dari kaum TRIWANGSA, artinya: tidaklah direndahkan lagi" (Surya Kanta 1926, No 1: 9-10).
\end{abstract}

This is to say that status in Balinese society should no longer be ascribed but achieved: it should stem from merit and not from birth. This, claimed Surya Kanta, concurs with the teachings found in Balinese lontar (such as the Sarasamuscaya) as well as in the sacred books of India (particularly the Bhagawadgita), which state that a true Brahmana is not someone who is born into a Brahmana family (Brahmana-turunan), but someone who lives up to Brahmana ideals (Brahmana-budi):

\begin{abstract}
"Meskipun Brahmana (turunan) sekalipun, kalau ia tiada menetapi sesana (darma), tiadalah patut dihormati, dan walaupun Sudra (turunan) kalau ia menjalankan darmanya, tertib sopan santun, puji dan hormatilah ia, kata Sanghyang Aji [...] Perjalanan atau sesana Brahmana itu dapat sempurna dilakukan oleh segala orang yang sanggup melakukannya, misalnya oleh orang yang berkepandaian dan budiman (bangsawan-fikiran) karena itulah sesana yang terutama [...] dari kaum Jaba pun tidak ada halangannya medwijati, asal beliau sanggup melakukan kewajibannya kelak" (Surya Kanta 1925, No. 1: 5).
\end{abstract}

Now, let's consider the way Tjakra Tanaja reacted to such a frontal attack on the triwangsa's prerogatives. He made his views known in the issue of Bali Adnjana published immediately after the launching of Surya Kanta in October 1925. Without ever mentioning Surya Kanta, he imparted his forceful opinion regarding status within Balinese society by driving home that being a Brahmana or

5 This slogan was coined in 1917 by the Javanese journalist Mas Marco Kartodikromo, publisher of Doenia Bergerak, and later popularized by both Sukarno and the communists (Shiraishi 1990: 88-90). 
a Sudra has nothing to do with budi but everything with asal usul turunannya:

"PadabangsaBALIHINDUadalahpadaLAHIRNYAPERTINGKATAN kebangsaan atau KAWONGAN (ingat Tuan! bukan BUDI lo'), yang diteguhkan atau ditetapkan oleh asal usul turunannya [...] Menjadi BRAHMANA, SATRYA, WESYA dan SUDRA itu adalah nama KAWONGANNYA dan sekali kali bukan BUDINYA, artinya IDA BAGUS KANGIN belum tentu lebih BUDINYA dari pada KTUT KELOD tetapi KAWONGANNYA nyatalah sudah KELEBIHANNYA" (Bali Adnjana 1925, No. 29: 2).

Upon which, he declared his intentions (tujuan) as (1) reconciling the Balinese people (perdamaian), (2) strengthening the religion (keteguhan berlakunya Agama), (3) changing its outdated customs (perobahan adat yang sudah kurang baik pada jaman ini), and (4) eliminating the oppression of insolent people (menghapuskan tindasannya si angkara murka) (Bali Adnjana 1925, n²9: 2). So far, so good, in the sense that whenever he wants to, Tjakra Tanaja proves able to argue his point quite explicitly. But then, rather curiously, he concluded his plea by stating: "Bukti bukti maksud saya sebagai berikut:", followed by "Percakapan A dan B", a recurrent rhetorical device of his, where we encounter the very first mention of Surya Kanta.

In this pseudo-conversation betwen Tjakra Tanaja (A) and his imaginary interlocutor (B), A explains to $B$ that he recently met a friend of his from Lombok, who asked him:

"Hai, A, bagaimanakah kabarnya perkumpulan SURYA KANTA di Buleleng, apa sudah banyakkah ledennya?".

In response to which he pretended to know nothing about it:

"Mendengar pertanyaan itu, akupun terkejut hingga tercengang sebab di Buleleng aku belum sekali pernah mendengar perkataan SURYA KANTA, dan akupun lantas menjawab dengan sebenarnya mengatakan bahasa di Buleleng belum ada terdengar perkumpulan semacam itu".

His disclaimer was met with disbelief by his friend:

"Ach, A, kamu jangan sembunyi akan hal itu sebab tahu sama tahu. Pendeknya sekarang aku kasih tahu padamu yang disini sekarang sudah 
berdiri cabang perkumpulan SURYA KANTA [...] Mustahil sekali kalau kamu bilang tidak tahu dan sedikit hari lagi akan mengeluarkan Maanblad (surat kabar bulanan) dan namanyapun SURYA KANTA".

At this point, B asked A whether he inquired about the aims of this new association. To which A replied with scathing sarcasm:

\begin{abstract}
"Aku ya tanya, tetapi rupanya sobat ku tidak mau menerangkan sama sekali, cuma katanya akan mengembangkan pengajaran mencapai kesempurnaan budi supaya lantas bisa mempunyai perasaan sama rata sama rasa pada sekalian manusia yang juga sama saja keadannya sebelum berbudi. Apabila dikemudian hari jika sudah berbudi disitulah akan ditentukan derajatnya artinya jikalau orang bisa melakukan dharmanya atau Sesana Brahmana haruslah mendapat pujian dan kehormatan sebagai Brahmana walaupun itu orang berasal bangsa Sudra sekalipun. Sebaliknya meskipun bangsa Brahmana sekalipun jikalau tidak berbudi, sama saja dengan Sudra".
\end{abstract}

To which B added in connivance:

"Wah kalau begitu jadinya umpama ada orang nama Pan Dama dan lantas bisa melakukan dharmanya atau Sesananya Brahmana lantas saja musti diberi kehormatan dan pujian secara seorang Ida Bagus Kaler yang juga sudah melakukan dharmanya yaitu menjadi Ida Padanda Dama. Apa memang begitulah tujuannya?".

That a jaba could pretend to become a padanda was plainly inadmissible for a triwangsa. Hence A's reply:

“Waaah B, kalau aku ingat ingat itu kabar lantas bulu kalongku berdiri, sebab bagaimanakah akan perasaannya kaum Triwangsa apabila benar begitu tujuannya itu perkumpulan?" (Bali Adjnana 1925, n²9: 3).

In the ensuing issue of Bali Adnjana, Tjakra Tanaja inserted a brief - but considerate - acknowledgement of Surya Kanta, even going so far as wishing its leaders every success for their initiative, which he claimed to support:

"SURYA KANTA. Begitulah nama SURAT KABAR BULANAN yang mengunjungi kantor Redactie Bali Adnjana. Terlebih dahulu saya mengucap beribu banyak terima kasih tentang kedermawaannya pengurus SURYA KANTA melontarkan surat bulanannya kepada saudaranya BALI ADNJANA. Menilik PENDAHULUAN dalam SURYA KANTA itu, maka saya bersetuju sekali dengan haluannya 
Tuan N [Ktoet Nasa] dan mudah mudahan tercapailah maksudnya yaitu MEMIMPIN bangsa Bali yang terbilang 'gelap' budinya enz. Dengan pendiriannya SURYA KANTA ini mudah mudahanlah kemajuan tanah $B A L I$ dan LOMBOK tentang HIDUP di DUNIA dan KEALUSAN BUDI bisa lekas tercapai. Sedangkan saya sebagai pengurus BALI ADNJANA sanggup juga sedapat dapat menyokong maksud itu, yang mana berlaku dengan cara DAMAI. Lanjutlah usianya SURYA KANTA dan KEKALLAH persaudaraannya dengan surat kabar MINGGUAN BALI ADNJANA. Hormat saya Redacteur B.A. I.G.TJAKRATANAJA" (Bali Adnjana 1925, No. 30: 5).

This acknowledgement is followed immediately by another Percakapan $A$ dan $B$. After having welcomed the publication of Surya Kanta ("Nah B. Ini lo lihat bagusnya surat kabar bulanan SURYA $\left.K A N T A^{\prime \prime}\right)$, A enjoins B to read it himself so that they could share their opinion regarding its purpose: "Marilah bersama sama membaca dan mengertikan supaya sedapat dapat jangan keliru penerimaan atau paham". B appears unsure of Surya Kanta's purpose, claiming that it is still too early to form an opinion: "Aku belum bisa mengatakan apa apa tentang hal tujuannya SURYA KANTA, sebab baru sekali terbit dan disitu belum ada pertimbangannya Redacteur terhadap pada karangannya PENGARANG". But then, proceeding by insinuation, he warns the editor of Surya Kanta about the risks incurred by the flame he has just ignited, as if it is not carefully handled it will not bring forth enlightenment to the Balinese but on the contrary set their nationhood alight:

"Cuma sekarang aku baru lihat ada api kecil sekali didalam SURYA KANTA yang dinyatakan oleh karangan yang berkepala PEMANDANGAN dan NGABEN. Aku rasa api itu akan berbahaya apabila Tuan Redacteurnya tidak lekas menguruskan itu api supaya bisa menjadi lampu penerangan dan jangan lantas menjadi api PEMBAKAR KEBANGSAAN" (Bali Adnjana 1925, No. 30: 5).

After this somewhat conciliatory - or rather sarcastic - start, the exchanges between Ktoet Nasa and Tjakra Tanaja grew more aggressive, while the latter kept on accusing Surya Kanta's leaders of being motivated by greed and envy in their foolish pursuit to abolish caste hierarchy. ${ }^{6}$ He warned them that, by challenging the

6 Tjakra Tanaja went occasionally further in his attack against Surya Kanta, which he accused of being a "lair of communists" (S.[arang] K.[ominis]), an accusation which, especially after the communist uprisings of 1926-27 in 
triwangsa, they were dividing the Balinese people, with the risk of weakening their resilience and of sowing dissension in their ranks. Not only did the Balinese inherit the hierarchical order from their ancestors but, furthermore, it is based on religious teachings found in lontar, which stipulate that one's current status is the fruit of one's karma:

"Siapakah Bali itu? Pada rasa penulis ialah sang CATURJADMA (Brahmana Satrya Wesya dan Sudra). Barang siapa merasaatau mengaku BALI, tetapi jikalau tidak menganggap adanya CATURJADMA tersebut diatas, tentulah kebaliannya itu hanya PULASAN saja atau sudah RUSAK karena menuruti hawa nafsu yang melupakan ADNYANA (fikir) [...] Dari sebab sekarang nyatanya kaum JABA sudah memisahkan diri pada sang Triwangsa, maka merasalah penulis bahasa keadaan kedua pihak itu kurang sampurna dan berarti juga cerai. Apabila perceraian itu terus menerus, tentulah berbahaya untuk nama BALI yang penulis terangkan diatas [...] Janganlah orang iri melihat atau mendengar orang SUDRA hormat kepada orang Triwangsa, walaupun yang tidak terpelajar sekalipun, sebab itulah memang sudah mesti menerima karmanya masing masing. Jikalau memang kepingin supaya juga bisa mendapat kehormatan Triwangsa, seharusnyalah supaya melakukan perbuatan yang utama supaya kemudian bisa mendapat karma yang lebih baik dari sekarang" (Bali Adnjana 1926, No. 2: 1-2).

Accordingly, it is very dangerous to challenge the caste system (sistem kasta) in Bali, as this would undermine the religious foundations of Balinese society - if only inasmuch as access to the status of padanda is the exclusive prerogative of Brahmana:

"Dengan lenyapnya Triwangsa, adalah berarti kelenyapannya peradaban dan Agama serta Adat yang bersifat Hindu Bali, sebab kaum Triwangsalah yang harus meneguhkan hal itu" (Bali Adnjana 1926, No. 17: 1).

\section{Upadeśa (1967)}

Once their island had become part of the Republic of Indonesia, the Balinese leaders were informed that the Ministry of Religions would not recognize their religion as a proper agama. Consequently, in order to make it eligible for the status of agama, they had to

Java and Sumatra and their ensuing repression, was a not too subtle way of arousing the colonial government's vigilance. 
rationalize their religion and redefine it in monotheistic terms, so as to make it look like a religion of the Book.

The first question to be settled was for the Balinese to agree on the name of their religion. After protracted debates, they resolved in 1952 to name their religion Agama Hindu Bali - the name advocated by the triwangsa back in the 1920s. Yet, if they had finally managed to reach an agreement among themselves, the Balinese still had to convince the Ministry of Religions of the legitimacy of the Agama Hindu Bali. While some religious leaders were looking for the seeds of regeneration in their own indigenous traditions, young Balinese who were studying in India urged their co-religionists to return to the fold of Hinduism, which they presented as the source of their rites. Stressing the theological import as well as the ethical purport of religion, they attempted to restrain the Balinese ritualistic leanings, while construing their Hindu heritage in accordance with Islam and Christianity.

In 1958, after years of lobbying, a Hindu Bali section was finally established within the Ministry of Religions. The next step was to decide who should be in charge of the Agama Hindu Bali, now that the kings of yore, who had previously been the patrons of the religious ceremonies on the island, had been replaced by the Republican government. For that purpose, a council was set up in 1959 to coordinate the religious activities of the Hindu Balinese the Parisada Dharma Hindu Bali 7.

During the 1960s, the growing presence of Balinese communities outside their own island enabled the Parisada to extend its influence across the Archipelago. Cut off from their temple networks as well as their deified ancestors, these Balinese migrants needed a delocalized and scriptural religion which they could carry with them. In these circumstances, the Parisada's leaders who had studied in India advocated giving up the exclusive name Agama Hindu Bali in favour of the more inclusive one Agama Hindu, in order to strengthen the position of their religion vis-à-vis Islam and Christianity. As a result, at the time of its first congress, in 1964, the Parisada Dharma Hindu Bali changed its name to Parisada Hindu

7 We notice that instead of the word agama, rejected on account of its Islamic connotation, it is the word dharma - used in India by Hindu reformers and their orthodox opponents alike to convey the normative notion of "religion" - which was chosen by former Balinese students from Indian universities. 


\section{UPADESA}

Tentang Ajaran=Ajaran
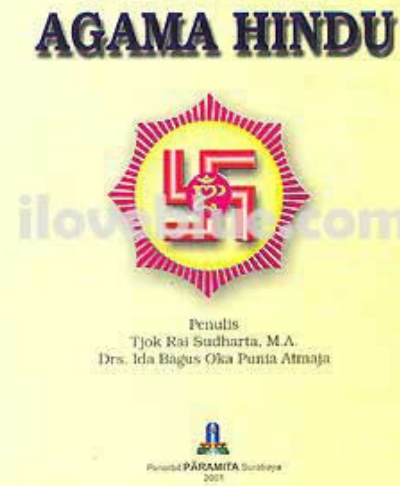

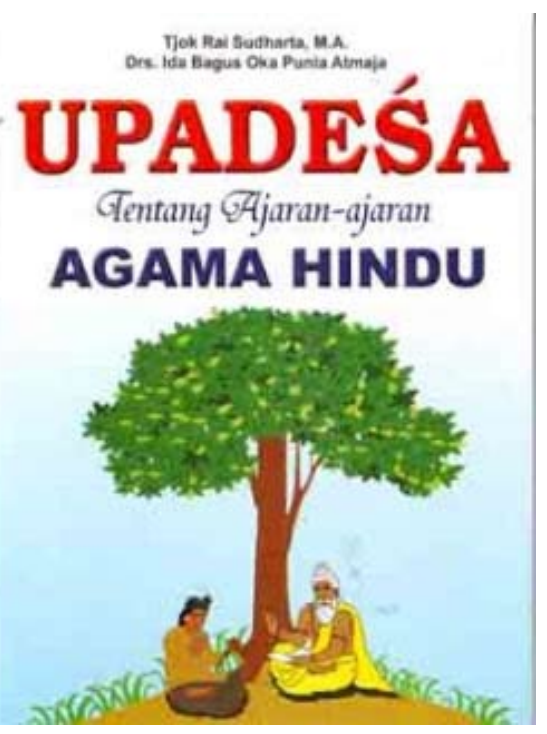

Photo 5. Upadeśa book on different covers.

Dharma, forsaking any reference to its Balinese origins. From then on, the name Hindu Dharma ${ }^{8}$ would become interchangeable with Agama Hindu - construed as "agama universal" (Dana 2005).

With the backing and subsidies of the provincial government, the Parisada undertook to translate Indian sacred scriptures, compile a theological canon, publish a Hindu catechism, standardize religious rites, formalize the priesthood, and provide religious instruction to the population - all of this amounting to a "scripturalization" of Balinese religion, a shift in focus from ritual to text. Whereas hitherto ritual practices were followed inasmuch as they had been handed down from generation to generation, from then on they were held to be motivated on the basis of prior belief. Thus, unlike the kings and the priests, who merely interceded on behalf of their subjects and clients, the Parisada was now instructing the Balinese on what to believe and how to practise their religion accordingly.

During the Parisada's 1964 congress, its founder and general

8 On the other hand, some of the Parisada's leaders disagreed with the name Hindu Dharma and proposed to replace it with Sanatana Dharma - the "eternal and universal religion" - a label endorsed by both Hindus reformers and traditionalists, as a manifestation of self-assertion against Christianity (Halbfass 1988: 343-346). 
secretary Ida Bagus Mantra drew up the theological canon of Agama Hindu, composed of five articles of faith - the Panca Çraddha - conceived on the model of the five pillars of Islam: belief in the one and only God (Sang Hyang Widhi), in the eternal essence of life (atman), in the retribution of all actions (karmaphala), in reincarnation (samsara), and in the final liberation (moksa) (Punyatmadja 1970)9.

Once the dogmatic contents of the Agama Hindu had been fully delineated, Ida Bagus Mantra set about composing a Hindu catechism, the Upadeśa Tentang Ajaran-Ajaran Agama Hindu (PHD 1967). ${ }^{10}$ This catechism has been constantly republished since then.

A catechism is a doctrinal manual for the instruction of catechumens, most often in the form of questions followed by answers to be memorised. This question and answer format establishes a dialog between an instructor and his pupils. The very idea of catechism is Protestant in origin, as Protestants had to reflect on what was truly the Christian religious doctrine, as opposed to its alleged corruption by the Roman Catholic Church. Martin Luther published his first catechisms in 1529 - one for children and another one for adults.

I have been able to trace two precedents for this Balinese catechism, both originating in the Theosophical Society - Colonel Henry Steel Olcott's A Buddhist Catechism (1881), and Annie Besant's Sanâtana Dharma Catechism (1902).

Colonel Henry Steel Olcott, the co-founder and first president of the Theosophical Society (1875), is credited with initiating the revival of Buddhism in Ceylon (Prothero 1995) - a revival characterized as "Buddhist Modernism" by Heinz Bechert (1966; see McMahan 2008) and as "Protestant Buddhism" by Gananath Obeyesekere (1970; see Gombrich \& Obeyesekere 1988). In effect, Olcott introduced into modern Sinhalese consciousness the notion of Buddhism as a system of beliefs through the publication of his Buddhist Catechism (Olcott 1881), modelled upon Protestant

9 While such a dogmatic formulation was a novelty, its theological framework had in fact already been laid out by Narendra Dev. Pandit Shastri (1955), an Indian reformer, follower of the Arya Samaj, who had come to Bali in 1949 and would prove instrumental in obtaining the official recognition of the Balinese religion.

10 The Sanskrit term upadeśa has the meaning of "teaching, instruction", in the sense of the spiritual guidance provided by a guru to his disciple. 
catechisms, which has gone through numerous editions and been translated into many languages, and which is still in use in Sri Lankan schools.

Olcott' A Buddhist Catechism, According to the Canon of the Southern Church opens in the following manner (Olcott 1881: 1):

1. Q. Of what religion are you?

A. The Buddhist.

2. Q. What is a Buddhist?

A. One who professes to be a follower of our Lord Buddha and accepts his doctrine.

Now, it is interesting that Annie Besant, who would later succeed Olcott as president of the Theosophical Society, composed a Hindu catechism entitled Sanâtana Dharma Catechism. A Catechism for Boys and Girls in Hindu Religion and Morals, published in 1902 by the Central Hindu College, which she had founded with a group of Indian theosophical colleagues in 1898 at Banaras (Besant 1902). The Catechism was followed by a more extensive manual entitled Sanâtana Dharma: An Elementary Textbook of Hindu Religion and Ethics, published in 1903 by the Central Hindu College (Besant et al. 1903a). This is the first textbook produced in English for classroom use on the part of Hindus themselves. And it was itself followed the same year by an even more extensive manual entitled Sanâtana Dharma: An Advanced Textbook of Hindu Religion and Ethics (Besant et al. 1903b; see Hawley 2009).

At the time, Hindus were more or less in the same position as early Protestants had found themselves, inasmuch as Hinduism was no longer taken for granted, being threatened by both Christian missionaries and Hindu reformers. Therefore, they were in need of knowing what their religion was really about and inclined to look into its sacred texts in order to establish a theological canon - which is the very idea of sanātana dharma.

Besant's Sanâtana Dharma Catechism opened in the following manner (Besant 1902: 3):

BASIC PRINCIPLES of HINDUISM.

$Q 1$. What is the meaning of the words Sanâtana Dharma?

A. Sanâtana means eternal; Dharma means religion.

Q. 2. To what religion is this name given? 
A. It is given to the Hindu religion, which is the oldest of the religions now in the world.

Q. 3. Is this the only reason for giving to it the name eternal?

A. No. It is also given because the great truths taught in it are eternal.

Q. 4. What is its foundation?

A. The Four Vedas, namely, the Rigveda, the Yajurveda, the Sâmaveda, the Atharvaveda. These were spoken by the Rishis, holy men taught by Brahmâ, and teach us how to worship and what to believe.

Q. 5. Are there any other books given by Rishis?

A. Yes. There are the Laws of Manu, the great Purânas, and the two histories, the Râmâyana and the Mahâbhârata. These are the chief books from which we learn the Sanâtana Dharma.

Coming back to the Balinese Upadeśa, we infer from the foreword how Ida Bagus Mantra initiated the project. Following the Parisada's congress, he assembled a team of seven contributors: Ida Pedanda Gde Wayan Sidemen (Ketua Umum Parisada Hindu Dharma), Ida Bagus Gede Dosther (Sekjen Parisada Hindu Dharma), Ida Bagus Oka Punia Atmaja (Dosen Fakultas Sastra Universitas Udayana), Tjokorda Rai Sudharta (Kepala Kantor Agama Propinsi Bali), Ida Bagus Alit (Kepala Bagian Peradilan Kantor Agama Propinsi Bali), and I Nyoman Mereta (staf Bagian Pendidikan Kantor Agama Propinsi Bali). The story goes that all the contributors were confined during two weeks at the home office of Ida Bagus Mantra in Denpasar until they achieved the composition of the catechism, which was then edited by Tjokorda Rai Sudharta to be finally published in 1967.

The 86 pages long Upadeśa is the first publication devoted to exposing the teachings of Agama Hindu. It is programmatic and seeks to encapsulate in a systematic fashion a coherent doctrine of what Agama Hindu is about. This doctrine is presented in the form of an imaginary dialogue between the guru R̦și Dharmakīrti ("Dharma's Glory") and his śișya Sang Suyaśa ("He Who Is Renowned") Percakapan Rṣi Dharmakīrti dengan Sang Suyaśa - a rhetorical device which brings to mind the characteristic composition of the Upanisad. Yet, even if this dialogue is structured along questions and answers, like a catechism, the guru's answers are not designed to be learnt by heart by his sisya, as they are rather elaborate and not always 
straightforward.

A preamble from the Kepala Kantor Daerah Direktorat Jenderal Pendidikan Dasar Departemen Pendidikan dan Kebudayaan Provinsi Bali informs the readers that the catechism is to be used for the courses in Agama Hindu in primary and secondary schools. A second preamble, by the Direktur Jenderal Bimbingan Masyarakat Beragama Hindu dan Budha Departemen Agama R.I., calls for the composition of other manuals for the instruction of Agama Hindu in colleges. ${ }^{11}$

The Upadeśa first introduces R̦și Dharmakīrti, whose knowledge of the Weda is reputed. He is visited in his ásrama Jagadhita by Sang Suyaśa, who is in search of sacred knowledge (pengetahuan suci). Sang Suyaśa respectfully salutes (pangañjali) R̦̣i Dharmakīrti with the greeting "Om Swastyastu", to which the guru replies with "Om Śānti, Śānti, Śānti”. Then Sang Suyaśa explains in flowery language the reason for his visit: "Oh, Guru suci, yang hamba muliakan, maafkanlah keberanian hamba yang datang ke hadapan Guru untuk memohon pengajaran-pengajaran suci dan berguna yang dapat memberikan sinar dan tuntunan pada jiza hamba yang dalam kegelapan ini". He has heard that, in the past, the rși were able to achieve eternal peace (kedamaian abadi) and everlasting bliss (kebahagiaan yang kekal). If this happens to be true, how could one achieve such a state? To which R̦si Dharmakīrti replies that this is indeed true and that this state can be achieved by anyone who follows the guidance of religion according to the teachings of the sacred Weda with a pure heart and single mindedness (jika telah mengalami tuntunan agama sesuai dengan ajaran-ajaran pustaka suci Weda dengan suci hati dan tulus ikhlas).

After this introduction, the Upadeśa proper is divided into 15

11 Formal religious education was still a relative novelty in Bali in the 1960s. It had started on a very limited scale in the colonial times, prompted by the new modern organizations that were being set up in the 1920s and 1930s, and then again after the end of the Japanese occupation, with the foundation of the Perguruan Rakjat Saraswati and the Jajasan Dwidjendra. The Perguruan Rakjat Saraswati was opened in Denpasar by I Gusti Made Tamba in 1946, with a curriculum inspired by the Taman Siswa and the educational ideas of Rabindranath Tagore. The Jajasan Dwidjendra was established in Denpasar by I Wajan Reta and Ida Bagus Wajan Gede in 1953, and soon after it opened a religious high school, the Sekolah Menengah Hindu Bali "Dwidjendra". It is worth noting that Narendra Dev. Pandit Shastri was actively involved in both these institutions. On Hindu education in Bali, see Nala (2004). 
chapters. In the first one, Rși Dharmakirti explains the meaning of Om Swastyastu (Semoga ada dalam keadaan baik atas karunia Hyang Widhi) and Om Śānti, Śānti, Śānti (Semoga damai atas karunia Hyang Widhi), as well as of the swastika, which is the sacred symbol of Agama Hindu (yang merupakan dasar kekuatan dan kesejahteraan bhuwana agung dan bhuwana alit).

Chapter2 is titled AgamaHindu (Hindu Dharma). R̦și Dharmakīrti provides the etymology of the word agama: the preposition /a-/ is privative and $/ \mathrm{gam} /$ means "to go". From which he infers that agama signifies "that which does not change, which is eternal" (langgeng). Unfortunately, this etymology is faulty, as in Sanskrit the preposition $/ \bar{a}-/$ of $\bar{a} g a m a$ is long and means "toward". Therefore aggama signifies "that which has come down to the present", and it refers to "anything handed down as fixed by tradition" (Gonda 1973: 499). This faulty etymology notwithstanding, R̦și Dharmakīrti defines agama as "dharma dan kebenaran abadi yang mencakup seluruh jalan kehidupan manusia". He explains that the Agama Hindu has been revealed by Sang Hyang Widhi and has originated in the region of the river Sindhu (diwahyukan oleh Sang Hyang Widhi yang diturunkan ke dunia, dan pertama kalinya berkembang di sekitar sungai suci Sindhu).

Rṣi Dharmakīrti elaborates further that Agama Hindu is the religion of the people who follow the teachings of the Weda sacred scriptures, which have been revealed by Sang Hyang Widhi. In the Weda, it is said (tersebut): "mokșārtham jagadhitāya ca iti dharma", which means that dharma (or agama) is what enables one to reach liberation (mukti) and well-being (bhukti). The fundamental framework (kerangka dasar) of Agama Hindu comprises three inseparable aspects - tattwa (filsafat), susila (ethica), and upacara (ritual) $)^{12}$ - which

12 This frameword had already been suggested by Roelof Goris in 1953, when he came to the rescue of the Balinese religious leaders who were struggling to have their religion recognized by the Ministry of Religions. In an article published by the magazine Bhakti, he stated that the Agama Hindu Bali - as a legitimate branch of Hinduism - was a proper religion and not an incoherent mixture of archaic traditions and mere superstitions. Among other erudite considerations, he asserted that every religion worthy of the name comprised three components: a creed (syahadat), a code of ethics (kesusilaan), and a liturgy (ibadat) (Goris 1953). This would not be lost on the Balinese reformers, who would soon emphasize the dogmatic contents and the ethical principles of the Agama Hindu Bali, in order to depreciate the ritualistic inclination of their co-religionists. In effect, we remark that 
are the equivalent of the head, the heart and the limbs for human beings.

Then R̦̣i Dharmakirti enunciates the five absolute beliefs (kepercayaan mutlak) professed by Agama Hindu, the Pañca Śraddhā, whose articles are expounded in the ensuing chapters: Percaya adanya Sang Hyang Widhi, Ātma, Hukum Karma Phala, Samsāra, dan Moksa.

Chapter 3 pertains to Widhi Tattwa (filsafat tentang Sang Hyang Widhi). Prompted by a question from Sang Suyaśa (siapa Sang Hyang Widhi itu?), R̦̣i Dharmakīrti explains that Sang Hyang Widhi is God the Almighty as Creator, Preserver, and Destroyer (Yang Maha Kuasa sebagai Pencipta, Pemelihara, Pemralina). Sang Hyang Widhi is the One and Only God, as it is said in the sacred Weda: "ekam ewa adwitìyam brahman"13. He pursues by explaining that, according to the functions He performs, Sang Hyang Widhi is named Brahmā as Creator (utpatti), Wiṣnu as Preserver (sthiti), and Śiwa as Destroyer (pralina), who together compose the Tri Śakti.

Sang Suyaśa then asks whether Sang Hyang Widhi is identical to Dewa or Bhatțāra. To which R̦și Dharmakīrti replies "No my son" (Tidak anakku), Dewa and Bhațtāra, which in Sanskrit signify both "divinity", are but emanations (sinar) of Sang Hyang Widhi. Sang Suyaśa asks further how can one be convinced (meyakinkan) of Sang Hyang Widhi's existence. R̦̣̦i Dharmakīrti explains that, according to Agama Hindu, there are three means of knowledge (tripramāna), that is, Pratyakșa-pramāna (perception), Anumānapramāna (inference), and Āgama-pramāna (authoritative scripture). Each of these pramanna are means to acknowledge the existence of Sang Hyang Widhi.

Sang Suyaśa then asks if certain "pure beings" (orang suci)

both the catechism and the textbooks published by Annie Besant were divided into the same three parts - theology ("Basic Hindu Religious Ideas"), rites ("General Hindu Religious Customs and Rites"), and ethics ("Ethical Teachings") - just like British Protestants catechisms at that time.

13 This is the wellknown mahāvākya from the Chāndogya Upaniṣad - "God is one, without a second". This profession of faith is somewhat reminiscent of the Islamic syahadat - "There is no god but God" - to which the Balinese had to conform in accordance with the instructions prescribed by the Ministry of Religions. In effect, this mahāvākya had already been put forward in 1952, when the Balinese were compelled to come up with their own profession of faith, which was then labelled "syahadat". 
are actually able to see Sang Hyang Widhi. R̦si Dharmakīrti begins by explaining that with their limited (terbatas) capacities human beings cannot see Sang Hyang Widhi, Who is unlimited. But the fact we cannot see Him does not mean that He does not exist. In effect, whoever lives a pure life, in accordance with the instructions of religion (petunjuk agama) and the teachings of sacred scriptures (ajaran dalam pustaka suci), would be able indeed to see Sang Hyang Widhi.

Thereupon ensue diverse considerations on the creation of the universe as well as of humanity, based on the authority of the Weda, the Upanișad, and the Bhagawadgitā, even though the references appear to be mostly taken from Sāinkhya cosmology (which is not mentioned) - purușa and prakrti, triguna, pañca-buddhi-indriya and pañca-karma-indriya, pañca mahā bhūta, brahmāṇ̣̂a, sapta loka, sāẹrasa, tri-śarīra, bhuwāna agung and bhuwāna alit, etc. ${ }^{14}$

Chapter 4 deals with Ätma-Tattwa. R̦și Dharmakīrti explains that àtma is constituted of small sparks (percikan kecil) of Parama$\bar{A} t m a$, that is, Sang Hyang Widhi, that are present in all living creatures. The ätman of human beings is called jīwätman, which is what animates human beings. The ätman and the body are like a driver and its carriage. When a human being dies, his/her jīwātman, which is eternal, goes either to paradise (surga) or to hell (neraka), according to whether that person's life has been good or bad (śubha aśubha karma). After some time, the jīwātman will reincarnate (punarbhāwa) in a new being in accordance with its karmaphala. This will occur over and over until the jīwätman breaks away from its earthly bonds (moksa) to achieve eternal bliss and peace (kebahagiaan dan kedamaian abadi).

Chapter 5 deals with Hukum Karma Phala and starts with a question from Sang Suyaśa, who has difficulty following his guru's explanations. R̦și Dharmakīrti expounds how "action" (karma) brings about "fruits" (phala), that is, good actions (śubhakarma) bring good results, whereas bad actions (aśubhakarma) bring bad results. But Sang Suyaśa appears unconvinced, as in actual fact there are

14 In fact, it seems to me that the theology expounded in the Upadeśa tends to combine the monism of Vedānta with the dualism of Sānkhya, without detracting from the monotheism imposed by the Ministry of Religions. I find particularly striking the absence of any reference to Tantric Shaivism, however prevalent it is in Balinese erudite traditions. 
people who suffer even though their behaviour is exemplary. On the other hand, there are people who have an enjoyable life even though they behave badly. Acknowledging Sang Suyaśa's doubts, R̦și Dharmakīrti pursues by stating that there are in fact three kinds of "fruits of action" (phala karma): sañcita (the fruits of a former existence which have not been entirely consumed), prārabdha (the fruits of the present existence which have been entirely consumed), and kriyamāna (the fruits of the present existence which will be consumed in a subsequent existence). This explains that, sooner or later, in the present existence or in a subsequent one, one has to bear all the fruits of one's actions, as this is the law of karma. ${ }^{15}$

Chapter 6 deals with Punarbhāwa, which is glossed by R̦și Dharmakīrti as "kelahiran yang berulang-ulang" and which is also called penitisan or samsāra. The endless cycle of birth, death, and rebirth brings forth both happiness and suffering (suka duka). But even though the ultimate aim of human beings is to put an end to the cycle of rebirths by reaching liberation $(m o k s a),{ }^{16}$ our birth in this world as human beings is an opportunity for us to increase our enlightenment (kesempurnaan) in order to overcome our woes (kesengsaraan).

Thus chapter 7 broaches the subject of Moksa, the deliverance from karma phala and from samsāra. Mokșa can be attained by human beings in this world, when they are freed from earthly bonds (ikatan keduniawian), a state called jiwwanmukti. It is possible to achieve this state by steadfastly performing the Catur Yoga, the four ways (marga) of uniting oneself (menyatukan diri) with Sang Hyang Widhi: the way of knowledge (jūana), the way of devotion (bhakti), the way of action (karma), and the "royal" way (rāja), that consists in doing brata, tapa, yoga until one reaches samädhi. These ways are equivalent and should be chosen according to one's personality, character and ability. R̦̣i Dharmakīrti gives as an example the instructions imparted by Kṛṣna to Arjuna in the Bhagawadgìtā (II,

15 We are here reminded of Tjakra Tanaja, who referred to the law of karma in order to warrant the triwangsa's prerogatives, even though the Parisada endorses a conception of warna similar to that advocated by Surya Kanta.

16 This statement is at odds with the situation prevailing in Bali, as the ultimate aim of Balinese death rituals is not to liberate a transcendant atman from its earthly bonds but rather to bring about a reincarnation into the family line (see Hornbacher 2014). 
47), according to which one ought to act in accordance with one's duty without attachment to the results of one's actions.

Then, Sang Suyaśa asks what happens to the ätman when one has reached moksa: it becomes united with Sang Hyang Widhi and experiences eternal truth, awareness and happiness, that is, "sat cit ananda" in Sanskrit. Only the ätman that is free from the triguna (sattwa, rajas, tamas) is able to unite with Sang Hyang Widhi and can declare: "I am God" (Aku adalah Tuhan).

After having explained the Pañca Śraddhā, R̦̣i Dharmakīrti deals with the Awatāra in chapter 8. They are the embodiment of Sang Hyang Widhi, Who comes down to the world in order to help human beings to free themselves from suffering (kesengsaraan) and ignorance (awidy $\bar{a}$ ). In the Bhagawadgītā (II, 7), it is said: "Whenever the dharma starts collapsing and adharma prevails, I incarnate in the world in order to uphold the dharma". The Purāna mention ten awatāra from Wiṣnu: Matsya, Kūrma, Warāhā, Nārasimha, Wāmana, Parasurāma, Śrī Rāma, Śrī Kṛṣna, Buddha, and Kalki. Then Sang Suyaśa asks the difference between the awatāra and the rssi: while awatāra are embodiments of Sang Hyang Widhi in the world, rși are human beings who have attained mokșa. R̦̣ i Dharmakīrti proceeds with an account of the Indian and Javanese rssi who brought Agama Hindu to Bali: Wyāsa, Mārkaṇḍeya, Agastya, Tantular, Bharadah, Asthāpaka, Kuturan, and Dwijendra.

Chapter 9 deals with sacred scriptures, Pustaka Śuci or Śāstra Dharma. R̦și Dharmakīrti states that the holy book of Agama Hindu is the Weda, that is, the perfect and eternal knowledge regarding Sang Hyang Widhi and His instructions to human beings. This knowledge has been heard by the maharși and is thus called Śruti, and it is divided into four parts, called Catur Weda: Rg Weda, Yajur Weda, Sàma Weda, and Atharwa Weda. The Śruti includes further the Upanisad, the Bhagawadgittā, the Weda Parikrama, and the Kämahayanikan. Given the complexity of the teachings embraced by the Weda, it has been necessary to design specific formulations for those who would not be able to understand them. This is why the teachings of the Weda have been conveyed by means of other literary channels such as the Smrti (which include the sütra, the Manu Smrti and the Sārasamuccaya), the Purāna, and the Itihāsa (Rāmāyana and 
Mahābhärata). ${ }^{17}$ The Bhagawadgittā, which is part of the Mahābhārata, is dubbed the fifth Weda, because in it Sang Hyang Widhi teaches the sacred knowledge of the Weda anew, at a time when the world is suffering from adharma. ${ }^{18}$

At this point of the dialogue, Rși Dharmakīrti aks whether Sang Suyaśa does not tire of his explanations. To which his pupil replies by saying that he is the one who worries that Gurunda might be tired of providing all this precious instruction.

Chapter 10 deals with the holy days (Hari Suci) of the Agama Hindu: Nyepi and Śiwarātri, determined by the Śăka calendar (Iśākawarśa); Saraswatì, Pagerwesi, Galungan, and Kuningan, according to the pawukon.

Chapter 11 deals with holy places (Tempat Suci), called pura in the Agama Hindu, which are of four different kinds: (1) The pura dedicated to the worship of Sang Hyang Widhi and his manifestations, called Pura Kahyangan; (2) The pura established by spiritual masters and dedicated to their commemoration, called Pura Dang Kahyangan; (3) The functional pura, such as the ones set up on the shoreline (Pura Segara), in the ricefields (Pura Subak), or on the marketplaces (Pura Melanting); (4) The pura dedicated to the worship of those ancestors who have attained the status of Dewa or of Bhațāra, called Pura Dadya, Pura Kawitan, or Pura Padharman.

Rși Dharmakīrti goes on to explain that there are two kinds of Pura Kahyangan. The Pura/Kahyangan Tiga are dedicated to the worship of Sang Hyang Widhi in His manifestations as Triwiśesa: the Pura Desa/Bale Agung is dedicated to Brahmā as Creator, the Pura Puseh to Wișnu as Preserver, and the Pura Dalem to Bhațtāri Durgā (sakti Śiwa) as Destroyer. ${ }^{19}$ As for the Pura/Kahyangan Jagat,

17 Actually, according to Brahmanical orthodoxy, Śruti is composed of the Veda Samitā, with their respective Brāmaṇa, Áranyaka, and Upanișad, while Smrti includes the Smārta Sütra and Vedāinga, the Itihāsa, the Purāna, the Dharmaśāstra, and the Nìtiśästra.

18 One should remember that it is only in the 1930s that the Bhagawadgit $\bar{a}$ has become accessible to the Balinese, after it had been translated into Malay by the Muslim poet Amir Hamzah in the literary magazine Poedjangga Baroe (Hamzah 1933-1935). I.B. Mantra has produced a new translation, along with commentaries and the original Sanskrit text in 1967 (Mantra 1967).

19 I suspect that this interpretation is recent, notwithstanding that it is commonly attributed to Mpu Kuturan. Indeed, the terms kahyangan tiga do not appear in old Balinese inscriptions of the $11^{\text {th }}$ to $14^{\text {th }}$ centuries (Stuart-Fox 
located at the eight points of the compass as well as in the center of Bali, they protect the island against dangerous forces by keeping them at bay. This is followed by several lists of Balinese temples, organized in a more or less orderly fashion. ${ }^{20}$

Thereupon, Sang Suyaśa asks his guru about the Pura Agung Jagannāta [sic] in Denpasar, which possesses only a Padmāsana. This, explains R̦̣̦i Dharmakīrti is a symbol (lambang) of Sang Hyang Widhi's omnipotence in the form of the Mount Mahāmeru from which human beings obtain the am $\bar{r} t a$, the water of life (air suci kehidupan).

After this exposition of the theological contents (tattwa) of the Agama Hindu, the catechism loses its well-ordered presentation and the following chapters appear as something of a catch-all.

Chapter 12 deals with ethics (Suśilla) and is prompted by a question from Sang Suyaśa asking the meaning of the words "Tat twam asi". R̦și Dharmakīrti explains that they mean "He is you" (ia adalah kamu) and that they are the basis of Hindu ethics. ${ }^{21}$ Suśilla is defined further as a behaviour which conforms to the stipulations of dharma and of yajna, glossed as "holy sacrifice" (korban suci).

It is said that Sang Hyang Widhi created the universe by sacrificing Himself. Hence, we human beings are indebted (rna) to Sang Hyang Widhi, to Whom we have to pay our debt in return by performing yajña. There are three sorts of debts for a Hindu (tri rna): to the Dewa, the Pitra, and the Rși. This results in five sacrifices (pañca yajña): the Dewa-yajña, the Pitra-yajña, the Manusayajna, the Rssi-yajña, and the Bhüta-yajña (which are dealt with in the following chapter). These sacrifices must be performed by everyone, according to one's stage of life (äśrama) and one's social class (warna). Accordingly, R̦̣i Dharmakīrti expounds the Catur Āśrama (Brahmacāri, Gṛhastha, Wānaprastha, and Bhikșuka), as well as

2002: 23, note 4). Besides, one observes some confusion regarding both the pura desa and the pura puseh, which happen to be occasionally associated with Wisnu and Brahma respectively.

20 In this chapter, it is clear that the Balinese authors attempt - with doubtful success - to adjust the specific characteristic features of their own island to the normative framework of reform Hinduism.

21 This notwithstanding that such a formula, drawn from the Chāndogya Upanişad, is unknown in Balinese textual traditions (see Fox 2011 for a witty treatment of such a modern borrowing). 
the Catur Warna (Brāhmana, Kșatriya, Waiśya, and Śüdra). ${ }^{22}$

R̦și Dharmakīrti pursues the matter by expounding a series of classificatory schemes, such as Triwarga (Dharma, Artha, Kāma), Triguna (Sattwa, Rajah, Tamah) [sic], Sad-ripu, Sad-ātatāyi, Saptatimira, Trikāya pariśudha (Kāyika, Wācita, Mānacika), Pañca-yama brata, Pañca-niyama brata, Daśa-yama brata, Daśa-niyama brata, and Catur guru (guru pengajian, guru rupaka, guru wiśsșa, guru sejati).

Chapter 13 deals with rituals (Upacära), which are meant to achieve a relationship by means of yajñ between the ātman and parama-ātman, between human beings and Sang Hyang Widhi. Hindu rituals make use of implements (upakara) that help human beings to relate to Sang Hyang Widhi, such as the pratima, which are not to be confused with Sang Hyang Widhi but are only representations of His manifestations in the form that we imagine them to be. From there follows a description of the pañca yajña: the Dewa-yajña, the Pitra-yajña, the Manusa-yajña, the Rsi-yajña, and the Bhūta-yajña. ${ }^{23}$

Chapter 14 deals with worship (Cara Sembahyang). R̦și Dharmakīrti describes the different ways of worship (muspa), collective as well as individual, with their various implements: holy water (tìrtha), incense, flowers, and kewangen.

The last chapter is titled Trisandhyā, even though its contents is in fact rather heterogeneous. Rși Dharmakīrti expounds the trisandhyā as a prayer to Sang Hyang Widhi performed during the

22 One notices that the definition of the warna put forward by Rṣi Dharmakīrti corresponds to the version propounded by reform Hinduism and not to Balinese socio-historical reality. Indeed, according to the Parisada, one's warna is determined not by birth but by talent and function, a position already advocated by Surya Kanta in the 1920s. This perspective does'nt actually make sense in Bali, where the warna framework serves as a model for classifying kinship groups according to a contested hierarchy.

23 Like a number of recent formalizations, this categorization of Balinese rituals had been propounded by Narendra Dev. Pandit Shastri, who had put forward in 1951 a presentation close to the Vedic pañcamahāyajña, the five "great sacrifices" that a householder has to perform daily: devayajña (oblation to the fire), pitryajũa (offering of food and water), bhütayajña (offering of a rice ball or flowers), narayajna (offering of food to brahmins), and brahmāyajũa (recitation of Vedic mantra) (Shastri 1951). We notice further that the rites supposed to venerate Sang Hyang Widhi are called Dewayajña and not Widhi-yajña, which indicates that the recipients of this veneration are the dewa and not Sang Hyang Widhi, who was not the recipient of any yadnya before becoming the supreme God of Agama Hindu in Bali. 
"junctures" (saindhya) of the day: at dawn, at noon, and at dusk. It consists of a compilation of Sankrit mantra, the first of which is the well known Gāyatri, excerpted from the Rg Weda. ${ }^{24}$

As R̦̣i Dharmakīrti had indicated that after having recited the trisañdhyā one should make use of tìrtha, Sang Suyaśa asks how it is procured. He is told that only the pandita or sulinggih, those who have been initiated (didìksāa) and are thus "twice-born" (didwijātikan) have the right to produce tìrtha. They are the only priests allowed to guide the congregation (umat) and to supervise the rites (loka pālaśraya). The other priests, the pinandita, who have only been purified (diwinten), have to "ask" (nunas) for the tìrtha. Then R̦și Dharmakīti explains (in a very confuse manner) what the padiksan and the pawintenan consist of..$^{25}$

Thereupon Sang Suyaśa expresses his gratitude and pays his respects to R̦̣i Dharmakīrti with a pangañjali.

\section{Concluding remarks}

From the 1920s to the 1960s, the prevailing view of the Balinese religion has undergone sweeping changes, in both content and form, as testified by the contrast between Tjakra Tanaja's Percakapan $A$ dan $B$ and the Parisada's Percakapan Rși Dharmakìrti dengan Sang Suyaśa.

We remark that none of the questions most hotly debated between Surya Kanta and Bali Adnjana appear in the Upadeśa. For one thing, the competition between jaba and triwangsa is now considered close (even if we know that this is far from being the case), inasmuch as they are all fellow Hindus nowadays. Moreover, the differentiation between functions (warna) has been allegedly

24 Again, like so many other Hindu innovations, the trisandhyā has been formulated by Narendra Dev. Pandit Shastri (1951). But whereas, according to tradition, the Gāyatri could only be recited by Brahmana priests, the Puja Tri Sandya was promoted as the official prayer of Agama Hindu, in the manner of the Muslim salat (see Lanus 2014).

25 But he omits to mention that the initiation is monopolised by the Brahmana priests, the padanda, a privilege that was already contested, as we have seen, by Surya Kanta, and still is, not only by Balinese but also by the followers of Agama Hindu as a whole, notwithstanding that during its second congress, in 1968, the Parisada Hindu Dharma conceded the right for non-Brahmana (umat Hindu dari segala warga) to gain access to the status of pandita or sulinggih by being didiksa (Ketetapan Sabha Parisadha Hindu Dharma ke II Tahun 1968). 
substituted for the hierarchical distinction between titled groups (wangsa), in line with the interpretation pioneered by Surya Kanta. Then, the relationship between agama and adat on the one hand, and between Balinese religion and Hinduism on the other, is ostensibly no longer at stake. On the one hand, the reference to adat has all but disappeared in the discourse of Rși Dharmakīrti, and on the other, the Agama Hindu is now deemed "universal" and no longer peculiar to a specific ethnic group. Indeed, the debate on the proper name of the Balinese religion has been settled by depriving the Balinese of its exclusive ownership. Accordingly, the mention of Majapahit Java is no longer relevant and has been replaced by India as the source of the Balinese religion - the Indian sacred scriptures have superseded the Balinese lontar.

Besides, in the days of the polemics between Surya Kanta and Bali Adnjana, Balinese authors were still very much immersed in an oral and manuscript culture, whereas at the time of the composition of the Upadeśa, print culture had been pretty much appropriated. Hence we can expect different formulaic features from one culture to the other. In effect, we notice a shift away from the formulaic, parataxis, and codified copiousness toward the abstract, the analytical, and subordination (Sweeny 1987). More to the point, while Tjakra Tanaja's pseudo-dialog was elusive and allusive, full of innuendos and insinuations, the discourse of Rși Dharmakīrti is didactic, explicit, normative, and, above all, authoritative. Indeed, the Upadeśa is programmatic and attempts to encapsulate a complete doctrine of what Agama Hindu is about.

Yet, while the authority claimed by the Upadeśa is clearly buttressed by references originating in reform Hinduism, one gets the feeling that most of these references are just added on rather than articulated in a coherent fashion. Indeed, the taxonomic organisation of its topics appears more Indian than Balinese ${ }^{26}$ and this alien makeup plainly fails to account for the actual local practices. Hence an inescapable amount of confusion that grows messier as R̦si Dharmakīrti's narrative proceeds, not to mention some flagrant distorsions that present-day Balinese religious leaders are still busy striving to suture.

26 One notices that the authors tend to systematically substitute the vernacular Balinese terminology with a Sanskrit one, scrupulously transcribed with the proper diacritics. 


\section{REFERENCES}

Bechert, Heinz. 1966. Buddhismus, Staat und Geselschaft in den Ländern des Theravāda Buddhismus. Vol. 1. Frankfurt \& Berlin: Alfred Metzner,.

Besant, Annie. 1902. Sanâtana Dharma Catechism. A Catechism for Boys and Girls in Hindu Religion and Morals, The Board of Trustees. Benares: Central Hindu College.

Besant, Annie, et al. 1903a. Sanâtana Dharma: An Elementary Text-book of Hindu Religion and Ethics. Benares: The Board of Trustees, Central Hindu College.

Besant, Annie, et al. 1903b. Sanâtana Dharma: An Advanced Text Book of Hindu Religion and Ethics. Benares: The Board of Trustees, Central Hindu College.

Dana, I N., ed. 2005. Kompilasi Dokumen Literer 45 Tahun Parisada. Jakarta: Parisada Hindu Dharma Indonesia Pusat.

Fox, Richard. 2011. Critical Reflections on Religion and Media in Contemporary Bali. Leiden: Brill.

Gombrich, Richard F. \& Gananath Obeyesekere. 1988. Buddhism Transformed: Religious Change in Sri Lanka. Princeton: Princeton University Press.

Gonda, Jan. 1973. Sanskrit in Indonesia. New Delhi: International Academy of Indian Culture [1952].

Goris, Roelof, 1953, "Apakah: Ibadat Hindu Bali itu Agama atau Aliran?", Bhakti, 2/20: 10-13.

Halbfass, Wilhelm, 1988, India and Europe: An Essay in Understanding. New York : State University of New York Press [1981].

Hamzah, Amir. 1933-1935. Bhagawad-Gita diterdjemahkan oleh Amir Hamzah, Poedjangga Baroe : 1/1 (Juli 1933), 2/8 (Pebruari 1935).

Hawley, John Stratton. 2009. "Sanātana Dharma as the Twentieth Century Began. Two textbooks, two languages", in Ishita Banerjee-Dube \& Saurabh Dube, eds, Ancient to Modern. Religion, Power and Community in India. New Delhi: Oxford University Press, pp. 312-336.

Hornbacher, Annette. 2014. “Contested Moksa in Balinese Agama Hindu. Balinese Death Rituals between Ancestor Worship and Modern Hinduism", in Volker Gottowik, ed., Dynamics of Religion in 
Southeast Asia. Magic and Modernity. Amsterdam: Amsterdam University Press, pp. 237-259.

Lanus, Sugi. 2014. "Puja Tri Sandhyā: Indian Mantras Recomposed and Standardised in Bali", The Journal of Hindu Studies, 7/2: 243272.

Mantra, Ida Bagus, ed. 1967. Bhagawad-Gita, naskah Sanskreta, alih bahasa dan pendjelasan. Denpasar: Parisada Hindu Dharma Pusat.

McMahan, David L. 2008. The Making of Buddhist Modernism. Oxford \& New York: Oxford University Press.

Nala, Ngurah. 2004. "The Development of Hindu Education in Bali", in Martin Ramstedt, ed., Hinduism in Modern Indonesia. A minority religion between local, national, and global interests. London \& New York: RoutledgeCurzon-IIAS Asian Studies Series, pp. 76-83.

Obeyesekere, Gananath. 1970. "Religious symbolism and political change in Ceylon", Modern Ceylon Studies, 1/1: 43-63.

Olcott, Henry S. 1881. A Buddhist Catechism, According to the Canon of the Southern Church. London \& New York: The Theosophical Society, Buddhist Section.

PHD. 1967. Upadeśa Tentang Adjaran-Adjaran Agama Hindu. Denpasar: Parisada Hindu Dharma.

Prothero, Stephen. 1995. "Henry Steel Olcott and 'Protestant Buddhism”', Journal of the American Academy of Religion, 63/2: 281-302.

Punyatmadja, Ida Bagus Oka. 1970. Panca Çraddha. Denpasar: Parisada Hindu Dharma Pusat.

Shastri, Narendra Dev Pandit. 1951. Dasa Sila Agama Bali. Singaradja: np.

Shastri, Narendra Dev Pandit. 1955. Intisari Hindu Dharma. Denpasar: np.

Shiraishi, Takashi. 1990. An Age in Motion. Popular Radicalism in Java, 1912-1926. Ithaca: Cornell University Press.

Stuart-Fox, David J. 2002. Pura Besakih. Temple, Religion and Society in Bali. Leiden : KITLV Press.

Sweeny, Amin. 1987. A Full Hearing. Orality and Literacy in the Malay World. Berkeley \& Los Angeles: University of California Press. 